\title{
Citation:
}

Томов, М. (2018). За един нов подход при описанието на прилагателните имена в българския език (с оглед на разработването на нормативна граматика). Slavia Meridionalis, 18. https:// doi.org/10.11649/sm.1683

Tomov, M. (2018). Za edin nov podkhod pri opisanieto na prilagatelnite imena v bŭlgarskiia ezik (s ogled na razrabotvaneto na normativna gramatika). Slavia Meridionalis, 18. https:// doi.org/10.11649/sm.1683

\section{Милен Томов}

Институт за български език

Българска академия на науките

\section{За един нов подход при описанието на прилагателните имена в българския език (с оглед на разработването на нормативна граматика)}

Днес с пълно основание можем да твърдим, че граматичното проучване на българския език има вече дълга и богата традиция. Въпреки това обаче различните възможности за описание на езиковата система и структура все още не са изчерпани. В тази статия ще изложим по-общо подхода, принципите и критериите за обособяване на флективни типове на прилагателните имена в съвременния български книжовен език във връзка с разработването на нормативна граматика.

This work was supported by the Bulgarian Ministry of Education and Science.

Competing interests: no competing interests have been declared.

Publisher: Institute of Slavic Studies, Polish Academy of Sciences.

This is an Open Access article distributed under the terms of the Creative Commons Attribution 3.0 PL License (creativecommons.org/licenses/by/3.0/pl/), which permits redistribution, commercial and non-commercial, provided that the article is properly cited. ๑ The Author(s) 2018. 
Отнасянето на думите към даден клас в българските граматики, а и не само в тях, като цяло изхожда едновременно от семантично-граматичната им характеристика, а доста често в хода на граматичното описание се вмъква и стилистично-функционален коментар. В традиционната граматика нерядко се наблюдава смесване на синхронни и диахронни интерпретации, взема се под внимание и произходът на думите. В морфологичното описание се интерпретира едновременно морфо- и словообразувателната структура, а във връзка с отделни случаи се прилага и синтактичен анализ. Често едни и същи лексеми се разглеждат като различни части на речта.

За разлика от традиционния подход на граматично описание, прилагащ едновременно критерии от различни езикови равнища, подходът, който се използва с цел съставяне на нова нормативна граматика на българския език, е описание на инвентара от граматични форми, напълно независимо от семантиката, като целта на подобно абсолютно формално граматично описание е да се категоризират всички изменяеми лексеми в българския език в съответни флективни типове, като тези типове се представят в максимална пълнота и подробност. Подобна цел предопределя и изборът на морфологичния критерий като основен при описанието на формите на изменяемите части на речта - имената и глаголите, в книжовноезиковата граматична система ${ }^{1}$. Тук е уместно да посочим, че с оглед съставянето на нормативна граматика на българския език описанието на формите на прилагателните имена е съобразено със словника на Официалния правописен речник (Българска академия на науките, 2012), който е и актуалният действащ нормативен документ за българския език. По този начин се осигурява необходимото единство в описанието на материала и се осъществява директна приемственост в случай на извършване на евентуални промени при кодификацията на граматичната и правописната норма.

Самостоятелно описание на флективните типове на частите на речта в българския език с представяне на инвентара им от словоформи досега са предлагали Б. Кръстев (Кръстев, 1990) и Д. Попов (Попов, Симов, \& Видинска, 1998).

1 По подробно за проекта „Нормативна граматика на българския език“, за теоретичния подход и използваната терминология (флективна категория, флективен тип, морфотактика) вж. Станчева, Томов, Паскалев, Кунева, \& Микова (2017), както и цитираната там литература. 
Макар и изведени в табличен вид със стремеж към максимален обхват на лексиката, тези описания се опират на традиционната граматично-семантична подялба на части на речта и не вземат под внимание всички възможни делитбени признаци, които биха били релевантни за едно същинско морфологично описание на думите в езика. Поради това и броят на флективните типове, които се извеждат от двамата автори, е много по-малък от броя на типовете, изведени според стриктното прилагане на морфологичния критерий. Както ще бъде показано по-нататък, чрез последователното прилагане на този формален критерий нашето описание значително се разминава с описанията на Кръстев и Попов (най-вече при разпределението на местоименията между класовете на прилагателните и съществителните имена). Положенията на морфологичния подход за българския език са приложени последователно и успешно от В. Малджиева в труда ѝ Български език (Малджиева, 2009). На изходните принципни положения и използваната терминология в тази работа се опира в значителна степен и нашето изследване.

Според възприетия от нас морфологичен критерий прилагателните имена са един от трите основни именни класа, наред със съществителните и числителните имена. Като принадлежаща на флективен тип език, българската именна система притежава следните словоизменителни категории: членуване, число и род, а местоименията съществителни притежават и категорията лице. Тъй като българския език като цяло не притежава морфологична категория падеж, за основна формоизменителна категория се приема членуването. Класът на прилагателните имена се състои от думи, които притежават всички формоизменителни категории: род, число и членуване. Формоизменителните категории на прилагателните дават възможност според формалния морфологичен критерий към този клас да се отнесат следните видове думи:

- прилагателни в собствен смисъл;

- местоименни прилагателни - думи, които традиционната граматика отнася към класа на местоименията: показателни, притежателни, възвратни (само възвратно-притежателните), въпросителни, относителни, неорределителни, отрицателни, обобщителни.

- числителни прилагателни - думи, които които традиционната граматика отнася към класа на числителните: бройното числително един и редните числителни имена. 
В такъв случай наборът от форми за лексемите прилагателни в българския книжовен език ще бъде следният:

- Форми за ед.ч., м.р., неопределени;

- Форми за ед.ч., м.р., определени;

- Форми за ед.ч., ж.р., неопределени;

- Форми за ед.ч., ж.р., определени;

- Форми за ед.ч., ср.р., неопределени;

- Форми за ед.ч., ср.р., определени;

- Форма (форми) за мн.ч., неопределена;

- Форма (форми) за мн.ч., определена;

- Звателни форми

- Форми за допълнение при местоименните прилагателни

- Кратки форми при местоименните прилагателни

Както се вижда, при стриктното провеждане на морфологичния критерий традиционната класификация на частите на речта в българския език, опираща се освен на морфологични и на функционални-семантични и синтактични характеристики, претърпява промени. Причисляването на местоименията, традиционно описвани като самостоятелна част на речта, към групата на прилагателните според новата концепция за нормативна граматика разширява инвентара от форми на традиционния клас прилагателни имена (uM, $\boldsymbol{M} y$, си и под.). От възвратните местоимения към прилагателните имена се причисляват само възвратно-притежателните, като по този начин възвратно-личните местоимения попадат извън класа на прилагателните. За да се запази единството на парадигмата на местоименията обаче, падежните форми кого, някого, никого, когото, които по функция се съотнасят със съществителните имена, се включват в описанието на типа на съответното местоимение. Към класа на прилагателните, както вече посочихме, се присъединява и числителното бройно име един, което притежава форми за род (една, едно), форми за множествено число (едни) и членувани форми (единия (m), едната, едното, едните). Традиционнните неопределителни местоимения кой да е, какъв да е, 
който и да е, чий да е отпадат от описанието като полиегментни единици ${ }^{2}$. По същата причина се изключват и съставните числителни редни имена (двадесет и първи, сто и петдесети), а такъв е подходът и към формите за степенуване на прилагателните имена, присъстващи в някои от споменатите досегашни граматични описания (напр. Кръстев, 1990, с. 56-62). Като проява на аналитизъм в езика те също на този етап остават извън обхвата на нашето описание.

Причастията, които традиционната граматика включва в рамките на глагола (сегашно деятелно причастие, минало деятелно и минало страдателно причастие) пазят рекцията (синтаксиса) на глагола (застанал до вратата, решен да направи) и затова се описват в рамките на глаголната парадигма въпреки именното им словоизменение (застанал, застаналата, застаналите и т.н.). Причастията са регулярно изводими от глагола и описвайки ги в неговата парадигма, граматиката ще дава и инструкция за тяхното формообразуване.

\section{Принципи на групиране на прилагателните имена в отделни флективни типове. Признаци с класификационна стойност}

Релевантните признаци, според които прилагателните имена се групират в отделни флективни типове, са наличие на окончание/нулево окончание, комбинаториката на окончанията в лексемата, наличие на морфонологични, включително и акцентни промени при словоизменението, наличие на дублетност в някоя от формите на лексемата, отнасяща се към даден словоизменителния тип.

Наборът от флективни морфеми в рамките на лексемата и отношението между тях играе значителна роля предвид отнасянето на лексемите към отделни флективни типове. Най-важни във връзка с това са морфемите, носители на граматична информация, които са релевантни за определянето на даден самостоятелен флективен тип.

\footnotetext{
2 За принципите на формалното описание на полисегментните единици вж. Малджиева, 2017.
} 
Като допълнителен критерий за обособяване на флективни типове се използва синтактичната функция, изпълнявана от лексемата (напр. разграничаване на местоимения прилагателни и местоимения съществителни; определянето на неизменяемите прилагателни (късметлия, екстра, ларж и под.). Синтактичният критерий за прилагателно име съдържа два компонента: 1) съчетава се със съществително; 2) намира се отляво на съществителното при немаркиран словоред. Но макар да е ясно, че разглежданите тук местоимения се употребяват като прилагателни имена, т.е. синтактичната им функция е на определения към названията на съответните обекти (в граматичните описания този факт между другото редовно се отбелязва), причисляването на местоименна лексика към класа на прилагателните имена произтича не толкова от функционално-синтактичната функция на местоименията, а преди всичко от категориалната (респективно формалната) общност на местоименните форми с формите на прилагателните имена, въпреки че съвпадението в това отношение не е абсолютно пълно.

Водещо при извеждането и подредбата на отделните флективни типове е наличието на форми, т.е. системната пълнота на парадигмата на лексемата, като след това се държи сметка за фонетичните промени. Този принцип на описание обаче не се провежда последователно и на места е нарушен, тъй като присъствието на различните признаци с делитбена стойност в думите (напр. наличие/липса на окончание или наличие/липса на фонетична промяна) могат да разместват флективните типове и да нарушават тяхната логична и най-вече линейна последователност, като по този начин придават известна условност на подреждането им. В граматичното описание всеки от обособените типове се илюстрира с представителна за него лексема, като в някои отделни случаи типовете образуват затворени множества (това важи най-вече за прилагателните местоимения) или са еднокомпонентни по отношение на състава си, т.е. представени са от една-единствена лексема (примери вж. по-долу).

Важна особеност на така очертания клас прилагателни имена е наличието на форми с нулево окончание и на

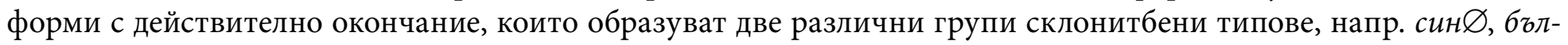
гарск-и. При прилагателните имена с нулево окончание се отбелязва удължаването на основата с -u-, след което е прибавен определителния член: син-и-я(m), прав-и-я(m), сам-и-я(m), скбn-u-я(m), негов-u-я(m). 
Като начало ще приведем пример за флективни типове приагателни имена, отделени по признака нулево окончание/наличие на окончание в основната форма (м.р. ед. ч.).

\begin{tabular}{|c|c|c|c|c|c|c|c|c|c|c|}
\hline $\begin{array}{l}\text { Окончание } \\
\text { за ед.ч. м.р. }\end{array}$ & $\begin{array}{c}\text { Членна форма } \\
\text { за ед.ч. м.р. }\end{array}$ & $\begin{array}{l}\text { Окончание } \\
\text { за ед.ч. ж.р. }\end{array}$ & $\begin{array}{c}\text { Членна форма } \\
\text { за ед.ч. ж.р. }\end{array}$ & $\begin{array}{l}\text { Окончание } \\
\text { за ср.p. }\end{array}$ & $\begin{array}{c}\text { Членна форма } \\
\text { за ед.ч. ср.p. }\end{array}$ & $\begin{array}{c}\text { Окончание } \\
\text { за мн.ч. }\end{array}$ & $\begin{array}{c}\text { Членна форма } \\
\text { за мн.ч. }\end{array}$ & $\begin{array}{c}\text { Форми } \\
\text { за допълнение }\end{array}$ & $\begin{array}{c}\text { Звателни } \\
\text { форми }\end{array}$ & $\begin{array}{l}\text { Кратка (место- } \\
\text { именна) форма }\end{array}$ \\
\hline $\begin{array}{l}\varnothing \\
\text { скЂ̀п } \\
\text { мил } \\
\text { драг }\end{array}$ & $\begin{array}{l}-И-Я Т \\
-И-Я \\
\text { сКБेП-И-Я(Т) }\end{array}$ & $\begin{array}{l}\text {-а } \\
\text { скъ̀па }\end{array}$ & $\begin{array}{l}\text {-та } \\
\text { скЂ̀пата }\end{array}$ & $\begin{array}{l}-0 \\
\text { скЂ̀по }\end{array}$ & $\begin{array}{l}\text {-то } \\
\text { скЂ̀пото }\end{array}$ & $\begin{array}{l}\text {-и } \\
\text { скЂ̀пи }\end{array}$ & $\begin{array}{l}\text {-те } \\
\text { скЂ̀пи-те }\end{array}$ & - & $\begin{array}{l}\text {-и } \\
\text { скЂ̀п-и } \\
\text { мѝл-и } \\
\text { дра̀г-и }\end{array}$ & - \\
\hline $\begin{array}{l}\text { Окончание } \\
\text { за ед.ч. м.р. }\end{array}$ & $\begin{array}{c}\text { Членна форма } \\
\text { за ед.ч. м.р. }\end{array}$ & $\begin{array}{l}\text { Окончание } \\
\text { за ед.ч. ж.р. }\end{array}$ & $\begin{array}{c}\text { Членна форма } \\
\text { за ед.ч. ж.р. }\end{array}$ & $\begin{array}{l}\text { Окончание } \\
\text { за ср.p. }\end{array}$ & $\begin{array}{c}\text { Членна форма } \\
\text { за ед.ч. ср.p. }\end{array}$ & $\begin{array}{c}\text { Окончание } \\
\text { за мн.ч. }\end{array}$ & $\begin{array}{c}\text { Членна форма } \\
\text { за мн.ч. }\end{array}$ & $\begin{array}{c}\text { Форми } \\
\text { за допълнение }\end{array}$ & $\begin{array}{c}\text { Звателни } \\
\text { форми }\end{array}$ & $\begin{array}{l}\text { Кратка (место- } \\
\text { именна) форма }\end{array}$ \\
\hline $\begin{array}{l}\text {-и } \\
\text { ѝстинск-и, } \\
\text { бь̀лгарск-и }\end{array}$ & $\begin{array}{l}\text {-И-ЯТ } \\
-И-Я \\
\text { йстинск-И-ЯТ }\end{array}$ & $\begin{array}{l}\text {-а } \\
\text { ѝстинск-а }\end{array}$ & $\begin{array}{l}\text {-та } \\
\text { ѝстинска-та }\end{array}$ & $\begin{array}{l}\text {-о } \\
\text { ѝстинск-о }\end{array}$ & $\begin{array}{l}\text {-то } \\
\text { ѝстинско-то }\end{array}$ & $\begin{array}{l}- \text { И } \\
\text { Ѝстинск-И }\end{array}$ & $\begin{array}{l}\text {-те } \\
\text { ѝстински-те }\end{array}$ & - & - & - \\
\hline
\end{tabular}

Следващата таблица илюстрира обособяването на два отделни флективни типа според комбинаторика на окончания във формата за ср.p. ед.ч. Допълнителен делитбен признак тук е и мекостта на крайния съгласен от основата във формата за ж.р. на прилагателното син.

\begin{tabular}{|c|c|c|c|c|c|c|c|c|c|c|}
\hline $\begin{array}{l}\text { Окончание } \\
\text { за ед.ч. м.р. }\end{array}$ & $\begin{array}{c}\text { Членна форма } \\
\text { за ед.ч. м.р. }\end{array}$ & $\begin{array}{l}\text { Окончание } \\
\text { за ед.ч. ж.р. }\end{array}$ & $\begin{array}{c}\text { Членна форма } \\
\text { за ед.ч. ж.р. }\end{array}$ & $\begin{array}{c}\text { Окончание } \\
\text { за ср.p. }\end{array}$ & $\begin{array}{c}\text { Членна форма } \\
\text { за ед.ч. ср.p. }\end{array}$ & $\begin{array}{c}\text { Окончание } \\
\text { за мн.ч. }\end{array}$ & $\begin{array}{c}\text { Членна форма } \\
\text { за мн.ч. }\end{array}$ & $\begin{array}{c}\text { Форми } \\
\text { за допълнение }\end{array}$ & $\begin{array}{c}\text { Звателни } \\
\text { форми }\end{array}$ & $\begin{array}{l}\text { Кратка (место- } \\
\text { именна) форма }\end{array}$ \\
\hline $\begin{array}{l}\varnothing \\
\text { бивш }\end{array}$ & $\begin{array}{l}\text {-И-Ят } \\
-И-Я \\
\text { бйвШ-И-Я(т) }\end{array}$ & $\begin{array}{l}\text {-a } \\
\text { бѝвш-а }\end{array}$ & $\begin{array}{l}\text {-та } \\
\text { бйвшата }\end{array}$ & $\begin{array}{l}-\mathrm{e} \\
\text { бѝвш-е }\end{array}$ & $\begin{array}{l}\text {-то } \\
\text { бйвше-то }\end{array}$ & $\begin{array}{l}\text {-и } \\
\text { бйвш-И }\end{array}$ & $\begin{array}{l}\text {-те } \\
\text { бйвши-те }\end{array}$ & - & - & - \\
\hline
\end{tabular}




\begin{tabular}{|c|c|c|c|c|c|c|c|c|c|c|}
\hline $\begin{array}{l}\text { Окончание } \\
\text { за ед.ч. м.p. }\end{array}$ & $\begin{array}{l}\text { Членна форма } \\
\text { за ед.ч. м.р. }\end{array}$ & $\begin{array}{l}\text { Окончание } \\
\text { за ед.ч. ж.р. }\end{array}$ & $\begin{array}{l}\text { Членна форма } \\
\text { за ед.ч. ж.р. }\end{array}$ & $\begin{array}{l}\text { Окончание } \\
\text { за ср.p. }\end{array}$ & \begin{tabular}{|c|} 
Членна форма \\
за ед.ч. ср.р.
\end{tabular} & $\begin{array}{c}\text { Окончание } \\
\text { за мн.ч. }\end{array}$ & $\begin{array}{c}\text { Членна форма } \\
\text { за мн.ч. }\end{array}$ & $\begin{array}{c}\text { Форми } \\
\text { за допълнение }\end{array}$ & $\begin{array}{c}\text { Звателни } \\
\text { форми }\end{array}$ & $\begin{array}{l}\text { Кратка (место- } \\
\text { именна) форма }\end{array}$ \\
\hline $\begin{array}{l}\varnothing \\
\text { син }\end{array}$ & \begin{tabular}{|l}
-И-Ят \\
-И-Я \\
сѝн-И-я(Т)
\end{tabular} & $\begin{array}{l}\text {-я [a] } \\
\text { сиेн-я }\end{array}$ & $\begin{array}{l}\text {-та } \\
\text { сйня-та }\end{array}$ & $\begin{array}{l}-\mathrm{o}[\mathrm{o}] \\
\text { сѝнь-O }\end{array}$ & $\begin{array}{l}\text {-то } \\
\text { сйньо-то }\end{array}$ & $\begin{array}{l}\text {-и } \\
\text { сйн-и }\end{array}$ & $\begin{array}{l}\text {-те } \\
\text { сйни-те }\end{array}$ & - & - & - \\
\hline
\end{tabular}

В следващата таблица се демонстрира пример за отделен флективен тип прилагателни имена с наличие на фонетична промяна - редуване я:е в членуваната форма за м.р., както и в членуваната и нечленувана форма за мн.ч.

\begin{tabular}{|c|c|c|c|c|c|c|c|c|c|c|}
\hline $\begin{array}{l}\text { Окончание } \\
\text { за ед.ч. м.р. }\end{array}$ & $\begin{array}{l}\text { Членна форма } \\
\text { за ед.ч. м.р. }\end{array}$ & $\begin{array}{l}\text { Окончание } \\
\text { за ед.ч. ж.р. }\end{array}$ & $\begin{array}{l}\text { Членна форма } \\
\text { за ед.ч. ж.р. }\end{array}$ & $\begin{array}{c}\text { Окончание } \\
\text { за ср.p. }\end{array}$ & $\begin{array}{l}\text { Членна форма } \\
\text { за ед.ч. ср.р. }\end{array}$ & $\begin{array}{c}\text { Окончание } \\
\text { за мн.ч. }\end{array}$ & $\begin{array}{l}\text { Членна форма } \\
\text { за мн.ч. }\end{array}$ & $\begin{array}{c}\text { Форми } \\
\text { за допълнение }\end{array}$ & $\begin{array}{c}\text { Звателни } \\
\text { форми }\end{array}$ & $\begin{array}{l}\text { Кратка (место- } \\
\text { именна) форма }\end{array}$ \\
\hline $\begin{array}{l}\varnothing \\
\text { бял }\end{array}$ & \begin{tabular}{|l}
-И-ят \\
-И-я \\
бѐл-И-я(т)
\end{tabular} & $\begin{array}{l}-\mathrm{a} \\
\text { бя̀л-a }\end{array}$ & \begin{tabular}{|l|}
-та \\
бя̀ла-та
\end{tabular} & \begin{tabular}{|l}
-о \\
бя̀л-о
\end{tabular} & \begin{tabular}{|l|}
-то \\
бя̀по-то
\end{tabular} & $\begin{array}{l}\text {-и } \\
\text { бѐл-и }\end{array}$ & $\begin{array}{l}\text {-те } \\
\text { бѐли-те }\end{array}$ & - & - & - \\
\hline
\end{tabular}

В съществуващите досега граматични описания прави впечатление отделното описание на фонетичните промени при образуването на формите на прилагателните за род и число (напр. ГСБКЕ, 1982; Стоянов, 1964 и др.). При описанието на дадена фонетична промяна обаче не се обособяват отделно случаите с форми, при които има повече от една

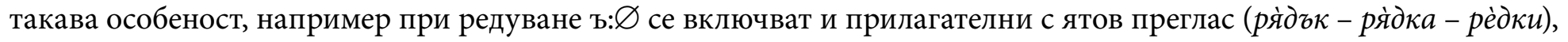

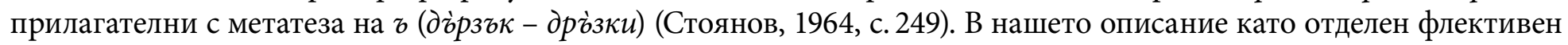
тип се извеждат прилагателните, при които е налице повече от една морфонологична промяна, напр. дързбк - типът се подразделя според едновременно наличие на промяната $p ъ-ъ p$ и редуване ъ: $\varnothing$ :

\begin{tabular}{|c|c|c|c|c|c|c|c|c|c|c|}
\hline $\begin{array}{l}\text { Окончание } \\
\text { за ед.ч. м.р. }\end{array}$ & $\begin{array}{c}\text { Членна форма } \\
\text { за ед.ч. м.р. }\end{array}$ & $\begin{array}{l}\text { Окончание } \\
\text { за ед.ч. ж.р. }\end{array}$ & $\begin{array}{c}\text { Членна форма } \\
\text { за ед.ч. ж.р. }\end{array}$ & $\begin{array}{l}\text { Окончание } \\
\text { за ср.p. }\end{array}$ & $\begin{array}{c}\text { Членна форма } \\
\text { за ед.ч. ср.p. }\end{array}$ & $\begin{array}{c}\text { Окончание } \\
\text { за мн.ч. }\end{array}$ & $\begin{array}{c}\text { Членна форма } \\
\text { за мн.ч. }\end{array}$ & $\begin{array}{c}\text { Форми } \\
\text { за допълнение }\end{array}$ & $\begin{array}{c}\text { Звателни } \\
\text { форми }\end{array}$ & $\begin{array}{l}\text { Кратка (место- } \\
\text { именна) форма }\end{array}$ \\
\hline $\begin{array}{l}\varnothing \\
\text { дъेрзък }\end{array}$ & \begin{tabular}{|l|}
-И-ят \\
- -И-я \\
дрЂेзк-и-я(т)
\end{tabular} & $\begin{array}{l}-a \\
\text { дрЂ̀зк-а }\end{array}$ & $\begin{array}{l}\text {-та } \\
\text { дръ̀зка-та }\end{array}$ & $\begin{array}{l}-о \\
\text { дръ̀зк-о }\end{array}$ & $\begin{array}{l}\text {-то } \\
\text { дрђ̀зко-то }\end{array}$ & $\begin{array}{l}-и \\
\text { дрЂ̀зк-и }\end{array}$ & $\begin{array}{l}\text {-те } \\
\text { дрЂ̀зки-те }\end{array}$ & - & - & - \\
\hline
\end{tabular}


В самостоятелни флективни типове се обособяват прилагателните, които притежават дублетни форми. За нормативната граматика от съществено значение е факът, че дублетността е естествено явление в книжовния език, тъй като лексикалният състав на езика претърпява постоянни промени. В следващата таблица представяме пример за обособяване на флективен тип според признака наличие на дублетност при числителното прилагателно двайсети.

\begin{tabular}{|c|c|c|c|c|c|c|c|c|c|c|}
\hline $\begin{array}{l}\text { Окончание } \\
\text { за ед.ч. м.р. }\end{array}$ & $\begin{array}{l}\text { Членна форма } \\
\text { за ед.ч. м.р. }\end{array}$ & $\begin{array}{l}\text { Окончание } \\
\text { за ед.ч. ж.р. }\end{array}$ & $\begin{array}{c}\text { Членна форма } \\
\text { за ед.ч. ж.р. }\end{array}$ & $\begin{array}{c}\text { Окончание } \\
\text { за ср.p. }\end{array}$ & $\begin{array}{c}\text { Членна форма } \\
\text { за ед.ч. ср.р. }\end{array}$ & $\begin{array}{c}\text { Окончание } \\
\text { за мн.ч. }\end{array}$ & $\begin{array}{c}\text { Членна форма } \\
\text { за мн.ч. }\end{array}$ & $\begin{array}{c}\text { Форми } \\
\text { за допълнение }\end{array}$ & $\begin{array}{c}\text { Звателни } \\
\text { форми }\end{array}$ & $\begin{array}{l}\text { Кратка (место- } \\
\text { именна) форма }\end{array}$ \\
\hline $\begin{array}{l}\text {-и } \\
\text { два̀йсет-и } \\
\text { и два̀десет-и }\end{array}$ & $\begin{array}{l}\text {-и-ят } \\
\text {-и-я } \\
\text { два̀йсети- } \\
\text { я(т) и два̀де- } \\
\text { сети-я(т) }\end{array}$ & $\begin{array}{l}\text {-а } \\
\text { два̀йсет-а } \\
\text { и два̀десет-а }\end{array}$ & $\begin{array}{l}\text {-та } \\
\text { два̀йсета-та } \\
\text { и два̀- } \\
\text { десета-та }\end{array}$ & $\begin{array}{l}\text {-о } \\
\text { два̀йсет-о } \\
\text { и два̀десет-о }\end{array}$ & $\begin{array}{l}\text {-то } \\
\text { два̀йсето-то } \\
\text { и два̀де- } \\
\text { сето-то }\end{array}$ & $\begin{array}{l}\text {-и } \\
\text { два̀йсет-и } \\
\text { и два̀десет-и }\end{array}$ & $\begin{array}{l}\text {-те } \\
\text { два̀йсети-те } \\
\text { и два̀де- } \\
\text { сети-те }\end{array}$ & - & - & - \\
\hline
\end{tabular}

По същия начин се обособяват и флективни типове с наличие на акцентна дублетност (напр. структурен и структуेрен, усто̀йчив и устойчѝв)

Според прилагания морфологичен критерий притежателните местоимения негов и нейн попадат в групата на прилагателните имена с нулево окончание, но се отделят в самостоятелен тип както поради наличието на кратка местоименна форма $(м y, \grave{u})$, така и поради липса на звателни форми:

\begin{tabular}{|c|c|c|c|c|c|c|c|c|c|c|}
\hline $\begin{array}{l}\text { Окончание } \\
\text { за ед.ч. м.р. }\end{array}$ & $\begin{array}{c}\text { Членна форма } \\
\text { за ед.ч. м.р. }\end{array}$ & $\begin{array}{l}\text { Окончание } \\
\text { за ед.ч. ж.р. }\end{array}$ & $\begin{array}{c}\text { Членна форма } \\
\text { за ед.ч. ж.р. }\end{array}$ & $\begin{array}{l}\text { Окончание } \\
\text { за ср.p. }\end{array}$ & $\begin{array}{c}\text { Членна форма } \\
\text { за ед.ч. ср.р. }\end{array}$ & $\begin{array}{c}\text { Окончание } \\
\text { за мн.ч. }\end{array}$ & $\begin{array}{c}\text { Членна форма } \\
\text { за мн.ч. }\end{array}$ & $\begin{array}{c}\text { Форми } \\
\text { за допълнение }\end{array}$ & $\begin{array}{c}\text { Звателни } \\
\text { форми }\end{array}$ & $\begin{array}{l}\text { Кратка (место- } \\
\text { именна) форма }\end{array}$ \\
\hline $\begin{array}{l}\varnothing \\
\text { скъп } \\
\text { мил } \\
\text { драг }\end{array}$ & $\begin{array}{l}\text {-И-ЯТ } \\
- \text {-И-Я } \\
\text { скБेП-И-Я(Т) }\end{array}$ & $\begin{array}{l}\text {-a } \\
\text { скъ̀па }\end{array}$ & $\begin{array}{l}\text {-та } \\
\text { скь̀пата }\end{array}$ & $\begin{array}{l}\text {-о } \\
\text { скЂ̀по }\end{array}$ & $\begin{array}{l}\text {-то } \\
\text { скЂ̀пото }\end{array}$ & $\begin{array}{l}\text {-и } \\
\text { скЂ̀пи }\end{array}$ & $\begin{array}{l}\text {-те } \\
\text { скЂ̀пи-те }\end{array}$ & - & $\begin{array}{l}\text {-и } \\
\text { скЂ̀п-и } \\
\text { мѝл-и } \\
\text { дра̀г-и }\end{array}$ & - \\
\hline
\end{tabular}




\begin{tabular}{|c|c|c|c|c|c|c|c|c|c|c|}
\hline $\begin{array}{l}\text { Окончание } \\
\text { за ед.ч. м.р. }\end{array}$ & $\begin{array}{l}\text { Членна форма } \\
\text { за ед.ч. м.р. }\end{array}$ & $\begin{array}{l}\text { Окончание } \\
\text { за ед.ч. ж.р. }\end{array}$ & $\begin{array}{l}\text { Членна форма } \\
\text { за ед.ч. ж.р. }\end{array}$ & $\begin{array}{c}\text { Окончание } \\
\text { за ср.p. }\end{array}$ & $\begin{array}{l}\text { Членна форма } \\
\text { за ед.ч. ср.р. }\end{array}$ & $\begin{array}{c}\text { Окончание } \\
\text { за мн.ч. }\end{array}$ & $\begin{array}{l}\text { Членна форма } \\
\text { за мн.ч. }\end{array}$ & $\begin{array}{c}\text { Форми } \\
\text { за допълнение }\end{array}$ & $\begin{array}{c}\text { Звателни } \\
\text { форми }\end{array}$ & $\begin{array}{l}\text { Кратка (место- } \\
\text { именна) форма }\end{array}$ \\
\hline $\begin{array}{l}\varnothing \\
\text { нѐгов }\end{array}$ & \begin{tabular}{|l}
-И-ят \\
-И-Я \\
нѐгов-И-я(Т)
\end{tabular} & $\begin{array}{l}\text {-a } \\
\text { нѐгова }\end{array}$ & $\begin{array}{l}\text {-та } \\
\text { нѐговата }\end{array}$ & \begin{tabular}{|l}
-о \\
нѐгов-о
\end{tabular} & \begin{tabular}{|l}
-то \\
нѐговото
\end{tabular} & $\begin{array}{l}\text {-и } \\
\text { нѐгови }\end{array}$ & $\begin{array}{l}\text {-те } \\
\text { нѐгови-те }\end{array}$ & - & - & му \\
\hline $\begin{array}{l}\text { Окончание } \\
\text { за ед.ч. м.р. }\end{array}$ & $\begin{array}{l}\text { Членна форма } \\
\text { за ед.ч. м.р. }\end{array}$ & $\begin{array}{l}\text { Окончание } \\
\text { за ед.ч. ж.р. }\end{array}$ & $\begin{array}{l}\text { Членна форма } \\
\text { за ед.ч. ж.р. }\end{array}$ & $\begin{array}{c}\text { Окончание } \\
\text { за ср.p. }\end{array}$ & $\begin{array}{l}\text { Членна форма } \\
\text { за ед.ч. ср.р. }\end{array}$ & $\begin{array}{c}\text { Окончание } \\
\text { за мн.ч. }\end{array}$ & $\begin{array}{l}\text { Членна форма } \\
\text { за мн.ч. }\end{array}$ & $\begin{array}{c}\text { Форми } \\
\text { за допълнение }\end{array}$ & $\begin{array}{c}\text { Звателни } \\
\text { форми }\end{array}$ & $\begin{array}{l}\text { Кратка (место- } \\
\text { именна) форма }\end{array}$ \\
\hline
\end{tabular}

От друга страна, както се вижда, двете прилагателни местоимения оформят и отделни флективни типове поради наличие на допълнителен признак - промяната на $\breve{u}$ в $u$ при словоизменението на прилагателното местоимение неин.

Ето как разликата в набора от форми (в дадения случай при формите за допълнение) отделя прилагателни местоимения в два различни типа (допълнителен признак тук е и наличието на отмет на ударението в първия флективен тип):

\begin{tabular}{|c|c|c|c|c|c|c|c|c|c|c|}
\hline $\begin{array}{l}\text { Окончание } \\
\text { за ед.ч. м.р. }\end{array}$ & $\begin{array}{l}\text { Членна форма } \\
\text { за ед.ч. м.р. }\end{array}$ & $\begin{array}{l}\text { Окончание } \\
\text { за ед.ч. ж.р. }\end{array}$ & \begin{tabular}{|c|} 
Членна форма \\
за ед.ч. ж.р.
\end{tabular} & $\begin{array}{c}\text { Окончание } \\
\text { за ср.p. }\end{array}$ & \begin{tabular}{|} 
Членна форма \\
за ед.ч. ср.р.
\end{tabular} & $\begin{array}{c}\text { Окончание } \\
\text { за мн.ч. }\end{array}$ & $\begin{array}{c}\text { Членна форма } \\
\text { за мн.ч. }\end{array}$ & $\begin{array}{c}\text { Форми } \\
\text { за допълнение }\end{array}$ & $\begin{array}{c}\text { Звателни } \\
\text { форми }\end{array}$ & $\begin{array}{l}\text { Кратка (место- } \\
\text { именна) форма }\end{array}$ \\
\hline $\begin{array}{l}-\varnothing \\
\text { кой } \varnothing \\
\text { еди-кой } \varnothing\end{array}$ & - & $\begin{array}{l}\text {-я̀ } \\
\text { ко-я̀ } \\
\text { еди-коя̀ }\end{array}$ & - & \begin{tabular}{|l}
-è \\
ко-ѐ \\
еди-коѐ
\end{tabular} & - & $\begin{array}{l}\text {-й } \\
\text { ко-й } \\
\text { еди-кой }\end{array}$ & - & \begin{tabular}{|l|}
-го̀ \\
(на) ко-го̀ \\
(на) еди-кого̀
\end{tabular} & - & - \\
\hline
\end{tabular}

\begin{tabular}{|c|c|c|c|c|c|c|c|c|c|c|}
\hline $\begin{array}{l}\text { Окончание } \\
\text { за ед.ч. м.р. }\end{array}$ & $\begin{array}{l}\text { Членна форма } \\
\text { за ед.ч. м.р. }\end{array}$ & $\begin{array}{l}\text { Окончание } \\
\text { за ед.ч. ж.р. }\end{array}$ & $\begin{array}{l}\text { Членна форма } \\
\text { за ед.ч. ж.р. }\end{array}$ & $\begin{array}{c}\text { Окончание } \\
\text { за ср.p. }\end{array}$ & $\begin{array}{l}\text { Членна форма } \\
\text { за ед.ч. ср.р. }\end{array}$ & $\begin{array}{c}\text { Окончание } \\
\text { за мн.ч. }\end{array}$ & $\begin{array}{l}\text { Членна форма } \\
\text { за мн.ч. }\end{array}$ & $\begin{array}{c}\text { Форми } \\
\text { за допълнение }\end{array}$ & $\begin{array}{c}\text { Звателни } \\
\text { форми }\end{array}$ & $\begin{array}{l}\text { Кратка (место- } \\
\text { именна) форма }\end{array}$ \\
\hline $\begin{array}{l}-\varnothing \\
\text { нечий } \varnothing \\
\text { ничий } ~\end{array}$ & - & $\begin{array}{l}\text {-я } \\
\text { нѐчи-я } \\
\text { нйчи-я }\end{array}$ & - & $\begin{array}{l}\text {-е } \\
\text { нѐчи-е } \\
\text { нйчи-е }\end{array}$ & - & $\begin{array}{l}\text {-и } \\
\text { нѐчи-и } \\
\text { нйчи-и }\end{array}$ & - & - & - & - \\
\hline
\end{tabular}


Във връзка с делитбените признаци е важно още веднъж да отбележим, че в сравнение с досегашните опити за извеждане на флективни типове на прилагателните имена (напр. Кръстев, 1990) настоящото деление отчита последователно и акцентните промени във формоизменението при определянето на словоизменителните типове, тъй като ударението като прозодично средство е неделима част от формалната страна на думата и освен това е непосредствено свързано с нормативната страна на езика. В граматиката на Ст. Стоянов например прилагателните бистьр и добър се разглеждат в рамките на типа, оформян според фонетичната промяна изпадане на $z$, без да се отчита допълнителната акцентна особеност при добы̀р (добра̀, добро̀ и т.н.) (Стоянов, 1964, с. 249). При описанието на отделните флективни типове в речника на К. Попов (Попов и др., 1998) действително се коментират разликите при ударенията в рамките на даден флективен тип, без обаче тези типове да се подразделят допълнително според наличието или липсата на акцентни промени в тях.

Следващите примери илюстрират флективни типове с разлика в ударението:

a)

\begin{tabular}{|c|c|c|c|c|c|c|c|c|c|c|}
\hline $\begin{array}{l}\text { Окончание } \\
\text { за ед.ч. м.р. }\end{array}$ & $\begin{array}{l}\text { Членна форма } \\
\text { за ед.ч. м.р. }\end{array}$ & $\begin{array}{l}\text { Окончание } \\
\text { за ед.ч. ж.р. }\end{array}$ & $\begin{array}{l}\text { Членна форма } \\
\text { за ед.ч. ж.р. }\end{array}$ & $\begin{array}{c}\text { Окончание } \\
\text { за ср.p. }\end{array}$ & $\begin{array}{c}\text { Членна форма } \\
\text { за ед.ч. ср.p. }\end{array}$ & $\begin{array}{c}\text { Окончание } \\
\text { за мн.ч. }\end{array}$ & $\begin{array}{l}\text { Членна форма } \\
\text { за мн.ч. }\end{array}$ & $\begin{array}{c}\text { Форми } \\
\text { за допълнение }\end{array}$ & $\begin{array}{c}\text { Звателни } \\
\text { форми }\end{array}$ & $\begin{array}{l}\text { Кратка (место- } \\
\text { именна) форма }\end{array}$ \\
\hline $\begin{array}{l}\varnothing \\
\text { прав }\end{array}$ & $\begin{array}{l}\text {-И-Ят } \\
\text {-И-Я } \\
\text { пра̀в-И-Я(т) }\end{array}$ & $\begin{array}{l}-\mathrm{a} \\
\text { пра̀ва }\end{array}$ & $\begin{array}{l}\text {-та } \\
\text { пра̀вата }\end{array}$ & $\begin{array}{l}-о \\
\text { пра̀во }\end{array}$ & $\begin{array}{l}\text {-то } \\
\text { пра̀вото }\end{array}$ & $\begin{array}{l}-и \\
\text { пра̀ви }\end{array}$ & $\begin{array}{l}\text {-те } \\
\text { пра̀ви-те }\end{array}$ & - & - & - \\
\hline $\begin{array}{l}\text { Окончание } \\
\text { за ед.ч. м.р. }\end{array}$ & $\begin{array}{c}\text { Членна форма } \\
\text { за ед.ч. м.р. }\end{array}$ & $\begin{array}{l}\text { Окончание } \\
\text { за ед.ч. ж.р. }\end{array}$ & $\begin{array}{l}\text { Членна форма } \\
\text { за ед.ч. ж.р. }\end{array}$ & $\begin{array}{c}\text { Окончание } \\
\text { за ср.p. }\end{array}$ & $\begin{array}{c}\text { Членна форма } \\
\text { за ед.ч. ср.р. }\end{array}$ & $\begin{array}{c}\text { Окончание } \\
\text { за мн.ч. }\end{array}$ & $\begin{array}{c}\text { Членна форма } \\
\text { за мн.ч. }\end{array}$ & $\begin{array}{c}\text { Форми } \\
\text { за допълнение }\end{array}$ & $\begin{array}{c}\text { Звателни } \\
\text { форми }\end{array}$ & $\begin{array}{l}\text { Кратка (место- } \\
\text { именна) форма }\end{array}$ \\
\hline $\begin{array}{l}\varnothing \\
\text { сам }\end{array}$ & \begin{tabular}{|l}
-И-Ят \\
$-И-Я$ \\
сам-й-Я(Т)
\end{tabular} & $\begin{array}{l}\text {-à } \\
\text { cam-à }\end{array}$ & $\begin{array}{l}\text {-та } \\
\text { сама̀-та }\end{array}$ & $\begin{array}{l}\text {-ò } \\
\text { cam-ò }\end{array}$ & $\begin{array}{l}\text {-то } \\
\text { само̀-To }\end{array}$ & $\begin{array}{l}\text {-ѝ } \\
\text { сам-ѝ }\end{array}$ & $\begin{array}{l}\text {-те } \\
\text { самѝ-те }\end{array}$ & - & - & - \\
\hline
\end{tabular}


б)

\begin{tabular}{|c|c|c|c|c|c|c|c|c|c|c|}
\hline $\begin{array}{l}\text { Окончание } \\
\text { за ед.ч. м.р. }\end{array}$ & $\begin{array}{l}\text { Членна форма } \\
\text { за ед.ч. м.р. }\end{array}$ & $\begin{array}{l}\text { Окончание } \\
\text { за ед.ч. ж.р. }\end{array}$ & $\begin{array}{c}\text { Членна форма } \\
\text { за ед.ч. ж.р. }\end{array}$ & $\begin{array}{c}\text { Окончание } \\
\text { за ср.p. }\end{array}$ & $\begin{array}{c}\text { Членна форма } \\
\text { за ед.ч. ср.р. }\end{array}$ & $\begin{array}{c}\text { Окончание } \\
\text { за мн.ч. }\end{array}$ & $\begin{array}{c}\text { Членна форма } \\
\text { за мн.ч. }\end{array}$ & $\begin{array}{c}\text { Форми } \\
\text { за допълнение }\end{array}$ & $\begin{array}{c}\text { Звателни } \\
\text { форми }\end{array}$ & $\begin{array}{l}\text { Кратка (место- } \\
\text { именна) форма }\end{array}$ \\
\hline $\begin{array}{l}\varnothing \\
\text { крь̀гъл } \\
\text { еднйчък }\end{array}$ & \begin{tabular}{|l}
-И-Ят \\
-И-Я \\
крыेгл-И-я(Т)
\end{tabular} & $\begin{array}{l}\text {-а } \\
\text { крьेгл-а }\end{array}$ & $\begin{array}{l}\text {-та } \\
\text { крь̀гла-та }\end{array}$ & $\begin{array}{l}-о \\
\text { крђेгл-о }\end{array}$ & $\begin{array}{l}\text {-то } \\
\text { крђेгло-то }\end{array}$ & $\begin{array}{l}-и \\
\text { крђेгл-и }\end{array}$ & $\begin{array}{l}\text {-те } \\
\text { крьेгли-те }\end{array}$ & - & - & - \\
\hline $\begin{array}{l}\text { Окончание } \\
\text { за ед.ч. м.р. }\end{array}$ & $\begin{array}{c}\text { Членна форма } \\
\text { за ед.ч. м.р. }\end{array}$ & $\begin{array}{l}\text { Окончание } \\
\text { за ед.ч. ж.р. }\end{array}$ & $\begin{array}{c}\text { Членна форма } \\
\text { за ед.ч. ж.р. }\end{array}$ & $\begin{array}{l}\text { Окончание } \\
\text { за ср.p. }\end{array}$ & $\begin{array}{c}\text { Членна форма } \\
\text { за ед.ч. ср.p. }\end{array}$ & $\begin{array}{c}\text { Окончание } \\
\text { за мн.ч. }\end{array}$ & $\begin{array}{c}\text { Членна форма } \\
\text { за мн.ч. }\end{array}$ & $\begin{array}{c}\text { Форми } \\
\text { за допълнение }\end{array}$ & $\begin{array}{c}\text { Звателни } \\
\text { форми }\end{array}$ & $\begin{array}{l}\text { Кратка (место- } \\
\text { именна) форма }\end{array}$ \\
\hline $\begin{array}{l}\varnothing \\
\text { добъ̀р }\end{array}$ & $\begin{array}{l}\text {-И-ят } \\
- \text {-И-я } \\
\text { добр-И-я(Т) }\end{array}$ & $\begin{array}{l}\text { - à } \\
\text { добр-à }\end{array}$ & $\begin{array}{l}\text {-та } \\
\text { добр à -та }\end{array}$ & $\begin{array}{l}-о \\
\text { добр-о }\end{array}$ & $\begin{array}{l}\text {-то } \\
\text { добро-то }\end{array}$ & $\begin{array}{l}-и \\
\text { добр-ѝ }\end{array}$ & $\begin{array}{l}\text {-те } \\
\text { добрй-те }\end{array}$ & - & $\begin{array}{l}-и \\
\text { добрѝ }\end{array}$ & - \\
\hline
\end{tabular}

При прилагателни местоимения, съдържащи в състава си словообразувателната частица еди-, засега е възприет подход на групиране по изменяемата основа, носеща категориалната информация: кой, еди-кой; какъв- еди-ка$\kappa ъ в$, инакъв, някакъв и т.н.; чий - еди-чий. Така в един и същ флективен тип попадат местоименията, съдържащи в словообразувателната си структура -кой, -какъв, -чиц̆, както е показано в следващата таблица.

\begin{tabular}{|c|c|c|c|c|c|c|c|c|c|c|}
\hline $\begin{array}{l}\text { Окончание } \\
\text { за ед.ч. м.р. }\end{array}$ & $\begin{array}{l}\text { Членна форма } \\
\text { за ед.ч. м.р. }\end{array}$ & $\begin{array}{l}\text { Окончание } \\
\text { за ед.ч. ж.р. }\end{array}$ & $\begin{array}{c}\text { Членна форма } \\
\text { за ед.ч. ж.р. }\end{array}$ & $\begin{array}{c}\text { Окончание } \\
\text { за ср.p. }\end{array}$ & $\begin{array}{c}\text { Членна форма } \\
\text { за ед.ч. ср.p. }\end{array}$ & $\begin{array}{c}\text { Окончание } \\
\text { за мн.ч. }\end{array}$ & $\begin{array}{c}\text { Членна форма } \\
\text { за мн.ч. }\end{array}$ & $\begin{array}{c}\text { Форми } \\
\text { за допълнение }\end{array}$ & $\begin{array}{c}\text { Звателни } \\
\text { форми }\end{array}$ & $\begin{array}{l}\text { Кратка (место- } \\
\text { именна) форма }\end{array}$ \\
\hline $\begin{array}{l}-\varnothing \\
\text { кой } \varnothing \\
\text { еди-кой } \varnothing\end{array}$ & - & $\begin{array}{l}\text {-я̀ } \\
\text { ко-я̀ } \\
\text { едИ-коя̀ }\end{array}$ & - & $\begin{array}{l}\text {-ѐ } \\
\text { ко-ѐ } \\
\text { еди-коѐ }\end{array}$ & - & $\begin{array}{l}\text {-ѝ } \\
\text { ко-ѝ } \\
\text { еди-кой }\end{array}$ & - & \begin{tabular}{|l|}
-го̀ \\
(на) ко-го̀ \\
(на) еди-кого \\
(на)
\end{tabular} & - & - \\
\hline
\end{tabular}




\begin{tabular}{|c|c|c|c|c|c|c|c|c|c|c|}
\hline $\begin{array}{l}\text { Окончание } \\
\text { за ед.ч. м.р. }\end{array}$ & $\begin{array}{l}\text { Членна форма } \\
\text { за ед.ч. м.р. }\end{array}$ & $\begin{array}{l}\text { Окончание } \\
\text { за ед.ч. ж.р. }\end{array}$ & $\begin{array}{l}\text { Членна форма } \\
\text { за ед.ч. ж.р. }\end{array}$ & $\begin{array}{c}\text { Окончание } \\
\text { за ср.p. }\end{array}$ & $\begin{array}{l}\text { Членна форма } \\
\text { за ед.ч. ср.р. }\end{array}$ & $\begin{array}{c}\text { Окончание } \\
\text { за мн.ч. }\end{array}$ & $\begin{array}{l}\text { Членна форма } \\
\text { за мн.ч. }\end{array}$ & $\begin{array}{c}\text { Форми } \\
\text { за допълнение }\end{array}$ & $\begin{array}{c}\text { Звателни } \\
\text { форми }\end{array}$ & $\begin{array}{l}\text { Кратка (место- } \\
\text { именна) форма }\end{array}$ \\
\hline $\begin{array}{l}\varnothing \\
\text { какъ̀в } \\
\text { едикакъ̀в } \\
\text { ѝнакъв } \\
\text { ня̀какъв } \\
\text { нйкакъв } \\
\text { вся̀какъв }\end{array}$ & - & $\begin{array}{l}\text {-а } \\
\text { какв-а̀ } \\
\text { еди-какв-а̀ } \\
\text { йнакв-а } \\
\text { ня̀какв-а } \\
\text { нйкакв-а } \\
\text { вся̀какв-а }\end{array}$ & - & \begin{tabular}{|l}
-о \\
какв-о̀ \\
еди-какв-о̀ \\
йнакв-о \\
ня̀какв-о \\
нйкакв-о \\
вся̀какв-о
\end{tabular} & - & \begin{tabular}{|l}
-и \\
какв-й \\
еди-какв-ѝ \\
йнакв-и \\
ня̀какв-и \\
нйкакв-и \\
вся̀какв-и
\end{tabular} & - & - & & - \\
\hline
\end{tabular}

Като отделен флективен тип с единствена съществуваща форма се изолират запазените в съвременния български език стари определени (сложни) форми на прилагателните имена: долни (Долни Дъбник), горни (Горни Богров), черни (Черни вргх):

\begin{tabular}{|c|c|c|c|c|c|c|c|c|c|c|}
\hline $\begin{array}{l}\text { Окончание } \\
\text { за ед.ч. м.р. }\end{array}$ & $\begin{array}{l}\text { Членна форма } \\
\text { за ед.ч. м.р. }\end{array}$ & $\begin{array}{l}\text { Окончание } \\
\text { за ед.ч. ж.р. }\end{array}$ & $\begin{array}{l}\text { Членна форма } \\
\text { за ед.ч. ж.р. }\end{array}$ & $\begin{array}{c}\text { Окончание } \\
\text { за ср.p. }\end{array}$ & $\begin{array}{l}\text { Членна форма } \\
\text { за ед.ч. ср.р. }\end{array}$ & $\begin{array}{c}\text { Окончание } \\
\text { за мн.ч. }\end{array}$ & $\begin{array}{l}\text { Членна форма } \\
\text { за мн.ч. }\end{array}$ & $\begin{array}{c}\text { Форми } \\
\text { за допълнение }\end{array}$ & $\begin{array}{c}\text { Звателни } \\
\text { форми }\end{array}$ & $\begin{array}{l}\text { Кратка (место- } \\
\text { именна) форма }\end{array}$ \\
\hline $\begin{array}{l}\text {-и } \\
\text { чѐрн-И } \\
\text { до̀лн-И } \\
\text { но̀в-И }\end{array}$ & - & - & - & - & - & - & - & - & - & - \\
\hline
\end{tabular}

Отделен флективен тип оформя и прилагателното късметлия, което има ограничен набор от форми - за м.р., членувана и нечленувана. Допълнителният класификационен признак синтактична функция на лексемата позволява отнасянето ѝ едновременно и към класа на съществителните имена, срв. кбсметлия човек, но голям късметлия.

В хода на граматичното описание се изолират форми, които участват единствено в състава на устойчиви съчетания, напр. бъдеще покрай редовна форма за ср.р. бъдещо - бъдеще време. 
Като еднословни единици собствените имена също могат да се категоризират в рамките на отделен флективен тип:

\begin{tabular}{|c|c|c|c|c|c|c|c|c|c|c|}
\hline $\begin{array}{l}\text { Окончание } \\
\text { за ед.ч. м.р. }\end{array}$ & $\begin{array}{l}\text { Членна форма } \\
\text { за ед.ч. м.р. }\end{array}$ & $\begin{array}{l}\text { Окончание } \\
\text { за ед.ч. ж.р. }\end{array}$ & $\begin{array}{l}\text { Членна форма } \\
\text { за ед.ч. ж.р. }\end{array}$ & $\begin{array}{c}\text { Окончание } \\
\text { за ср.p. }\end{array}$ & $\begin{array}{l}\text { Членна форма } \\
\text { за ед.ч. ср.р. }\end{array}$ & $\begin{array}{c}\text { Окончание } \\
\text { за мн.ч. }\end{array}$ & $\begin{array}{l}\text { Членна форма } \\
\text { за мн.ч. }\end{array}$ & $\begin{array}{c}\text { Форми } \\
\text { за допълнение }\end{array}$ & $\begin{array}{c}\text { Звателни } \\
\text { форми }\end{array}$ & $\begin{array}{l}\text { Кратка (место- } \\
\text { именна) форма }\end{array}$ \\
\hline $\begin{array}{l}\varnothing \\
\text { Петро̀в } \\
\text { Ста̀нчев }\end{array}$ & - & $\begin{array}{l}\text {-a } \\
\text { Петро̀в-a } \\
\text { Ста̀нчев-а }\end{array}$ & - & - & - & $\begin{array}{l}\text {-и } \\
\text { Петро̀в-и } \\
\text { Ста̀нчев-и }\end{array}$ & - & - & - & - \\
\hline
\end{tabular}

Нека сега илюстрираме как формите на числителното бройно един се вписват в морфологичната парадигма на прилагателните имена:

\begin{tabular}{|c|c|c|c|c|c|c|c|c|c|c|}
\hline $\begin{array}{l}\text { Окончание } \\
\text { за ед.ч. м.р. }\end{array}$ & $\begin{array}{c}\text { Членна форма } \\
\text { за ед.ч. м.р. }\end{array}$ & $\begin{array}{l}\text { Окончание } \\
\text { за ед.ч. ж.р. }\end{array}$ & $\begin{array}{c}\text { Членна форма } \\
\text { за ед.ч. ж.р. }\end{array}$ & $\begin{array}{c}\text { Окончание } \\
\text { за ср.p. }\end{array}$ & $\begin{array}{c}\text { Членна форма } \\
\text { за ед.ч. ср.р. }\end{array}$ & $\begin{array}{c}\text { Окончание } \\
\text { за мн.ч. }\end{array}$ & $\begin{array}{c}\text { Членна форма } \\
\text { за мн.ч. }\end{array}$ & $\begin{array}{c}\text { Форми } \\
\text { за допълнение }\end{array}$ & $\begin{array}{c}\text { Звателни } \\
\text { форми }\end{array}$ & $\begin{array}{l}\text { Кратка (место- } \\
\text { именна) форма }\end{array}$ \\
\hline $\begin{array}{l}\varnothing \\
\text { едйн }\end{array}$ & \begin{tabular}{|l}
-И-ят \\
-И-я \\
едѝния(т)
\end{tabular} & $\begin{array}{l}\text {-à } \\
\text { едн-à }\end{array}$ & $\begin{array}{l}\text {-та } \\
\text { една̀-та }\end{array}$ & $\begin{array}{l}\text {-о̀ } \\
\text { едн-о̀ }\end{array}$ & $\begin{array}{l}\text {-то } \\
\text { едно̀-то }\end{array}$ & $\begin{array}{l}\text {-й } \\
\text { едн-й }\end{array}$ & $\begin{array}{l}\text {-те } \\
\text { еднй-те }\end{array}$ & - & - & - \\
\hline
\end{tabular}

Както отбелязахме по-горе, съгласно морфологичния критерий редните числителни имена също се причисляват към класа на прилагателните имена и формите им се вписват в съответните обособени флективни типове:

\begin{tabular}{|c|c|c|c|c|c|c|c|c|c|c|}
\hline $\begin{array}{l}\text { Окончание } \\
\text { за ед.ч. м.р. }\end{array}$ & $\begin{array}{c}\text { Членна форма } \\
\text { за ед.ч. м.р. }\end{array}$ & $\begin{array}{l}\text { Окончание } \\
\text { за ед.ч. ж.р. }\end{array}$ & $\begin{array}{c}\text { Членна форма } \\
\text { за ед.ч. ж.р. }\end{array}$ & $\begin{array}{c}\text { Окончание } \\
\text { за ср.p. }\end{array}$ & $\begin{array}{c}\text { Членна форма } \\
\text { за ед.ч. ср.p. }\end{array}$ & $\begin{array}{c}\text { Окончание } \\
\text { за мн.ч. }\end{array}$ & $\begin{array}{c}\text { Членна форма } \\
\text { за мн.ч. }\end{array}$ & $\begin{array}{c}\text { Форми } \\
\text { за допълнение }\end{array}$ & $\begin{array}{c}\text { Звателни } \\
\text { форми }\end{array}$ & $\begin{array}{l}\text { Кратка (место- } \\
\text { именна) форма }\end{array}$ \\
\hline $\begin{array}{l}\varnothing \\
\text { то̀чен }\end{array}$ & $\begin{array}{l}\text {-И-ЯТ } \\
\text {-И-Я } \\
\text { то̀чн-И-Я(Т) }\end{array}$ & $\begin{array}{l}\text {-a } \\
\text { TòчH-a }\end{array}$ & $\begin{array}{l}\text {-та } \\
\text { то̀чна-та }\end{array}$ & $\begin{array}{l}-\mathrm{O} \\
\text { TÒчH-O }\end{array}$ & $\begin{array}{l}\text {-то } \\
\text { то̀чно-то }\end{array}$ & $\begin{array}{l}\text {-И } \\
\text { то̀чH-И }\end{array}$ & $\begin{array}{l}\text {-те } \\
\text { то̀чните }\end{array}$ & - & - & - \\
\hline сто̀тен & Сто̀тн-И-Я & сто̀тн-а & сто̀тна-та & сто̀тн-о & сто̀тно-то & сто̀тн-И & сто̀тни-те & & & \\
\hline
\end{tabular}


Накрая ще посочим и пример за флективен тип с еднокомпонентен състав.

\begin{tabular}{|c|c|c|c|c|c|c|c|c|c|c|}
\hline $\begin{array}{l}\text { Окончание } \\
\text { за ед.ч. м.р. }\end{array}$ & $\begin{array}{l}\text { Членна форма } \\
\text { за ед.ч. м.р. }\end{array}$ & $\begin{array}{l}\text { Окончание } \\
\text { за ед.ч. ж.р. }\end{array}$ & $\begin{array}{l}\text { Членна форма } \\
\text { за ед.ч. ж.р. }\end{array}$ & $\begin{array}{c}\text { Окончание } \\
\text { за ср.p. }\end{array}$ & $\begin{array}{l}\text { Членна форма } \\
\text { за ед.ч. ср.р. }\end{array}$ & $\begin{array}{l}\text { Окончание } \\
\text { за мн.ч. }\end{array}$ & $\begin{array}{l}\text { Членна форма } \\
\text { за мн.ч. }\end{array}$ & $\begin{array}{c}\text { Форми } \\
\text { за допълнение }\end{array}$ & $\begin{array}{c}\text { Звателни } \\
\text { форми }\end{array}$ & $\begin{array}{l}\text { Кратка (место- } \\
\text { именна) форма }\end{array}$ \\
\hline - & - & - & - & - & - & $\begin{array}{l}\text {-И } \\
\text { ра̀зн-И }\end{array}$ & $\begin{array}{l}\text {-те } \\
\text { ра̀зни-те }\end{array}$ & - & - & - \\
\hline
\end{tabular}

Разбира се, в новата класификация на лексемите от гледище на морфологичната форма не липсват проблемни случаи, за които трябва да се търси еднозначно решение (напр. реални ли са форми като бояк, гледен, доен и др.п.). Съществуват основания местоименията на -ци (мой, свой, твой, някой) да се отнесат към флективните типове прилагателни имена с нулево окончание (срв. нов $\varnothing$; в тях липсва и разширяването на основата с-и-), като в останалите форми се приеме, че е налице контракция (мои).

Допълнителен проблем за разрешаване в хода на граматичното описание представлява звателната форма на прилагателните имена като критерий за набелязване на отделни флективни типове, тъй като това е форма, която не съвпада с основната форма на думата. На този етап, както беше показано в някои от примерите, приемаме наличието на такава форма като системна особеност и релевантен признак за формалното описание на прилагателните имена, т.е. прилагателните, които имат звателна форма, образуват отделен флективен тип. Ето още един пример:

\begin{tabular}{|c|c|c|c|c|c|c|c|c|c|c|}
\hline $\begin{array}{l}\text { Окончание } \\
\text { за ед.ч. м.р. }\end{array}$ & $\begin{array}{l}\text { Членна форма } \\
\text { за ед.ч. м.р. }\end{array}$ & $\begin{array}{l}\text { Окончание } \\
\text { за ед.ч. ж.р. }\end{array}$ & $\begin{array}{l}\text { Членна форма } \\
\text { за ед.ч. ж.р. }\end{array}$ & $\begin{array}{l}\text { Окончание } \\
\text { за ср.p. }\end{array}$ & \begin{tabular}{|c|} 
Членна форма \\
за ед.ч. ср.p.
\end{tabular} & $\begin{array}{c}\text { Окончание } \\
\text { за мн.ч. }\end{array}$ & $\begin{array}{c}\text { Членна форма } \\
\text { за мн.ч. }\end{array}$ & $\begin{array}{c}\text { Форми } \\
\text { за допълнение }\end{array}$ & $\begin{array}{c}\text { Звателни } \\
\text { форми }\end{array}$ & $\begin{array}{l}\text { Кратка (место- } \\
\text { именна) форма }\end{array}$ \\
\hline \begin{tabular}{|l|}
$\varnothing$ \\
бѐден \\
любѐзен
\end{tabular} & \begin{tabular}{|l|}
-И-ят \\
-И-Я \\
бѐдн-И-Я(т)
\end{tabular} & $\begin{array}{l}\mathrm{a} \\
\text { бѐдн-а }\end{array}$ & \begin{tabular}{|l|}
-та \\
бѐдна-та
\end{tabular} & $\begin{array}{l}\text {-о } \\
\text { бѐдн-о }\end{array}$ & \begin{tabular}{|l|}
-то \\
бѐдно-то
\end{tabular} & $\begin{array}{l}\text {-и } \\
\text { бѐдн-и }\end{array}$ & $\begin{array}{l}\text {-те } \\
\text { бѐдни-те }\end{array}$ & - & \begin{tabular}{|l}
-и \\
бѐдни \\
любѐзни
\end{tabular} & - \\
\hline
\end{tabular}

Освен изброените по-горе класификационни признаци съществена роля при отнасянето на думи и форми към съответен флективен тип играе и нормативният критерий. В нашия случай той се прилага в различни пунктове - изключват се например остарели форми, които все още се описват от граматиките по традиция (кой-годе), 
а онези от тях, които все още са в употреба или проявяват някакви особености в употребата си (напр. в случаите, при които се наблюдават изключения), ще бъдат коментирани в нормативната част на граматиката (напр. формите всекиго, всекиму, долни, черни, бъдеще (време), формите това-онова/туй-онуй).

Разбира се, в настоящата статия не можем да изчерпим всички проблеми на класификацията на прилагателните имена според нововъзприетия морфологичен критерий и да представим подробно описание на отделните флективни типове. Тук изложихме само основните критерии и принципи, според които лексемите прилагателни се разпределят в един или друг флективен тип в хода на работата по съставянето на нормативна граматика на българския език. Като резултат от прилагането на новия подход словоизменението на прилагателните имена в съвременния български книжовен език се представя от 50 флективни типа, изведени въз основа на гореописаните делитбени признаци чрез стриктното прилагане на морфологичния критерий за граматично описание на езика, т.е. единствено от гледище на морфологичната форма, без оглед на останалите езикови равнища и най-вече без оглед на семантиката. Класифицирани по такъв начин, прилагателните имена се превръщат в интересен обект за нови лингвистични наблюдения.

\section{БИБЛИОГРАФИЯ}

Граматика на съвременния български книжовен език: Vol. 2. Морфология [ГСБКЕ]. (1982). София: БАН. Кръстев, Б. (1990). Морфология на българския език в 187 типови таблици. София: Наука и изкуство.

Малджиева, В. (2009). Български език. In П. Пипер (Ed.), Јужнословенски језици: Граматичке структуре и функиије (рр. 19-141). Београд: Београдска књига.

Малджиева, В. (2017). Принципи на формалното описание на полисегментните езикови единици в нормативната граматика на българския език. Български език, 64(2), 7-19.

Българска академия на науките. (2012). Официален правописен речник на българския език. София: „Просвета“. 
Попов, Д., Симов, К., \& Видинска, С. (1998). Речник за правоговор, правопис, пунктуация. София: Атлантис КЛ.

Станчева, Р., Томов, М., Паскалев, Н., Кунева, И., \& Микова, Л. (2017). Формално описание на инвентара от граматични средства в българския език (като етап от разработването на нормативна граматика). In Доклади от Международната юбилейна конференция на Института за български език „Проф. Любомир Андрейчин“ (София, 15-16 май 2017 година) (Vol. 2, pp. 107-112). София: Институт за български език. Retrieved from http://ibl.bas.bg/Proceedings_IBL_Conference_2017_Volume_II.pdf

Стоянов, С. (1964). Граматика на българския книжовен език: Фонетика и морфология. София: Наука и изкуство.

\section{BIBLIOGRAPHY}

\section{(TRANSLITERATION)}

Bŭlgarska akademiia na naukite. (2012). Ofitsialen pravopisen rechnik na bŭlgarskiia ezik. Sofiia: "Prosveta”.

Gramatika na sŭvremenniia bŭlgarski knizhoven ezik: Vol. 2. Morfologiia [GSBKE]. (1982). Sofiia: BAN.

Krŭstev, B. (1990). Morfologiia na bŭlgarskiia ezik v 187 tipovi tablitsi. Sofiia: Nauka i izkustvo.

Maldzhieva, V. (2009). Bŭlgarski ezik. In P. Piper (Ed.), Južnoslovenski jezici: Gramatičke strukture i funkcije (pp. 19-141). Beograd: Beogradska knjiga. Maldzhieva, V. (2017). Printsipi na formalnoto opisanie na polisegmentnite ezikovi edinitsi v normativnata gramatika na bŭlgarskiia ezik. Bŭlgarski ezik, 64(2), 7-19.

Popov, D., Simov, K., \& Vidinska, S. (1998). Rechnik za pravogovor, pravopis, punktuatsiia. Sofiia: Atlantis KL.

Stancheva, R., Tomov, M., Paskalev, N., Kuneva, I., \& Mikova, L. (2017). Formalno opisanie na inventara ot gramatichni sredstva v bŭlgarskiia ezik (kato etap ot razrabotvaneto na normativna gramatika). In Dokladi ot Mezhdunarodnata iubilěna konferentsiia na Instituta za bŭlgarski ezik "Prof. Liubomir Andrě̆chin" (Sofiia, 15-16 maĭ 2017 godina) (Vol. 2, pp. 107-111). Sofiia: Institut za bŭlgarski ezik. Retrieved from http://ibl.bas.bg /Proceedings_IBL_Conference_2017_Volume_II.p

Stoianov, S. (1964). Gramatika na bŭlgarskiia knizhoven ezik: Fonetika i morfologiia. Sofiia: Nauka i izkustvo. 


\section{O pewnym nowym podejściu w opisie przymiotników w języku bułgarskim (w kontekście opracowania gramatyki normatywnej)}

Artykuł przedstawia nowe podejście do opisu przymiotników w języku bułgarskim, oparte na wyraźnym rozróżnieniu formy i znaczenia poprzez zastosowanie wyłącznie kryterium morfologicznego. Relewantne cechy przymiotników są pogrupowane w typy fleksyjne na podstawie obecności lub braku końcówki, kombinatoryki końcówek w leksemie, występowania zmian morfonologicznych (w tym akcentu), alternacji we fleksji, oraz form obocznych. Formowanie typów fleksyjnych zgodnie z wyżej wymienionymi cechami dystynktywnymi zilustrowano przykładami, a następnie zaproponowano zmiany w tradycyjnej klasyfikacji części mowy.

Słowa kluczowe: przymiotniki, morfologia leksemów odmiennych, język bułgarski

\section{On a New Approach in Describing Adjectives in Bulgarian (with the Context of the Development of a Normative Grammar)}

The article presents a new approach in the description of adjectives in Bulgarian, one that is based on strict differentiation between form and semantics by applying a purely morphological criterion. The relevant features of the adjectives are grouped in separate inflection types based on the presence of ending or lack thereof, the lexeme's ending combinations, the presence of morphonological (including stress) changes (alterations) in inflection, as well as on the presence of doublet forms. The formation of inflectional types according to the above specified relevant features is illustrated with examples, followed by a proposal of changes to the traditional classification of the parts of speech.

Keywords: adjectives, morphology of inflected morphemes, Bulgarian language 


\section{Notka o autorze}

Milen Tomov (Милен Томов) (tomovm@ibl.bas.bg) - bułgarysta, specjalista w zakresie współczesnego języka bułgarskiego. Doktor, docent w Instytucie Języka Bułgarskiego Bułgarskiej Akademii Nauk. Autor publikacji: Теорията на езиковата култура в научноисторическа и методологична перспектива (2013), Фонетиката в пьрвите научни граматики на българския език (2015), За системноезиковата адекватност на съвременния български правопис (2015) i in. Współautor Официален правописен речник на българския език (2012) і Обициален правописен речник на българския език. Глаголи (2016). Zainteresowania naukowe: teoria języków literackich, kultura języka, teoria i historia bułgarskiej ortografii, historia językoznawstwa bułgarskiego.

Milen Tomov (tomovm@ibl.bas.bg) - Bulgarian Studies scholar specializing in modern Bulgarian language. Associate Professor at the Institute for Bulgarian Language, Bulgarian Academy of Sciences. Main publications: Теорията на езиковата култура в научноисторическа и методологична перспектива [The theory of language cultivation in a historical and methodological perspective] (2013), Фонетиката в първите научни граматики на българския език [Рhопеtics in earliest scientific grammars of Bulgarian] (2015), За системноезиковата адекватност на съвременния български правопис [On the language-systemic adequacy of modern Bulgarian orthography] (2015). Co-author in Официален правописен речник на българския език [Оfficial spelling dictionary of the Bulgarian language] (2012) and Официален правописен речник на българския език. Глаголи [Official spelling dictionary of the Bulgarian language. Verbs] (2016). Research interests: theory of literary languages and language cultivation, history and theory of Bulgarian orthography, history of Bulgarian linguistics 